\title{
CLEANLINESS IS THE MAIN GUARANTEE TO PREVENT COVID-19
}

\author{
Yermekbayeva Akbal Urdabaevna \\ Candidate of Medical Sciences, \\ Karakalpak Medical Institute \\ Nukus, Karakalpakstan, \\ Uzbekistan
}

Article DOI: https://doi.org/10.36713/epra4788

\begin{abstract}
ANNOTATION
Today, the whole world is facing to one of the biggest problems in the history of mankind, which is known as COVID-19. This paper is about the COVID-19 which is spreading all over the world. It also discusses about the symptoms of coronavirus, how it is transmitted to people and suggests several tips to prevent the disease.
\end{abstract}

KEY WORDS: COVID-19, SARS-CoV, coronavirus, infection, dry-cough, sneezing, fever

\section{DISCUSSION}

Human health is the wealth of society. Everyone should consider ways to stay healthy. It is obvious that a healthy person is in a good mood and always eager to work. Our people rightly say, "Health is a healthy soul". The future of our country, its development, children's prosperity, is in everyone's hands.

Health is a great wealth. If you are healthy, everything will be fine. A healthy person is happy and has a happy life. That is why I believe that the main task of every sensible citizen is to make every citizen be aware of the infectious disease that is spreading in the world today, that is, the coronavirus, and to advocate for its prevention on a daily basis. The flu kills many more people a year in the world. However, without treatment, a new infection can be even more dangerous. Coronavirus is a large group of viruses that are common in both animals and humans.

What is the mode of transmission of the coronavirus?

The coronavirus can be transmitted from person to person through droplets in the air (coughing, sneezing, talking), and can be transmitted through household items and through contaminated food or water. Therefore, each of us should cover our mouth with a towel when we sneeze, and wash our face and hands every hour before eating. As the friend of health is cleanliness, we need to keep our personal hygiene clean.

The following conditions must be met for a person to be healthy:

- Always keep your body, face, hands and clothes clean.

- Exercise and do sports.

- Eat vitamin-rich foods, fruits and vegetables.

From ancient times our ancestors paid special attention to cleanliness, when a guest came to the house, they poured water into a jug and a small copper basin to wash hands. Even members of family washed their hands and kept themselves clean at every meal.

"Cleanliness is the basis of health, Health is the basis of wealth," - said our people. Our wise people did not say this proverb in vain.

Today, the World Health Organization has declared a global emergency, and what do we think about this disease, which has caused such a stir on the planet? It is a name derived from the Latin words crowns (crown) or halos (circle). This is because the coronavirus looks like a combination of the two (crown and circle) under a microscope. This group of viruses includes several types that can harm humans. One is caused by the flu, the other is found in bats, camels and animals, and is now known in science as SARS (Severe and Acute Respiratory Syndrome) and MERS (Middle East Respiratory Syndrome). How 
did it come into existence? The virus appeared in the city of Wuhan in central China's Hubei Province. Many of those who first became infected were those who went to or worked in seafood markets. The store was immediately closed for investigation. Chinese medical experts initially said that the coronavirus was transmitted only from animals to humans, but now they have to admit that it is transmitted from person to person. It is expected that the geography of the disease will even expand.

What are the symptoms? Typical symptoms of this virus are fever, headache, dry cough and body tremors. In addition, the US Centers for Disease Control and Prevention reports that those infected with the more dangerous form of the coronavirus have shortness of breath, tremors, and, in severe cases, patients may develop pneumonia. How is it treated? Tests are currently underway to detect the mysterious virus. However, a vaccine to prevent this infection has not yet been developed. This means that it can be more dangerous than the common flu, which kills many people every year. Therefore, in order to prevent the spread of this dangerous disease, people infected with the coronavirus are isolated in hospitals and at home. Its symptoms are treated with painkillers and antipyretics. In addition, such patients are advised to drink plenty of water and rest until recovery. How are coronaviruses transmitted? Most coronaviruses are spread by coughing, sneezing, or being in contact with the infected people. According to scientists, the new virus is transmitted by inhalation when in close human-to-human contact. Is it more dangerous than SARS? So far, this virus is not more dangerous than SARS. The latter spread from China in 2002-2003, killing about 800 people. However, there is speculation that the mysterious coronavirus may become even more dangerous or infectious. It is unknown at this time what the consequences will be.

The virus, which is spreading across the continent, especially in China, is called Wuhan or New Coronavirus (2019-nCoV). Coronavirus is a large family of viruses that is common among animals, including camels, cattle, cats, and bats.

But most infected people say that they have no contact with animals. That is, it can be transmitted from person to person through the air, like the flu route. According to the latest data, the incubation period can last from 2 to 14 days.

How to avoid coronavirus infection? There is currently no vaccine to prevent $2019-\mathrm{nCoV}$ infection. Therefore, if you are traveling or afraid of the virus, the most effective way to prevent the disease is to avoid its effects.

Other safety ways are the same as for other respiratory diseases. Wash your hands often with soap or water.
1. If soap and water are not available, use an alcohol-based hand sanitizer.

2. Keep unwashed hands away from your eyes, nose and mouth.

3. Avoid contact with sick people.

4. Stay home when you are sick.

5 . When coughing or sneezing, cover your face with a towel and then throw it in the trash.

6. Clean and disinfect tools and surfaces you are in constant contact with.

7. These are daily habits that prevent the spread of many viruses. The CDC has special offers for travelers.

We are the descendants of such scholars as Abu Ali Ibn Sina, who for centuries have preserved the nobility of our people and made the greatest contribution to the history of medicine in the world. In Ibn Sina's medicine, the goal of medical science is not only to treat the patient, but also to prevent the onset or prevention of disease, to focus on health. Ibn Sina expressed his views on the existence of "small animals" that are invisible to the naked eye and that they can cause disease through air and water. Only 850 years later, L. Pasteur studied the role of microorganisms in the transmission of infectious diseases. The Canon of Medicine also deals with agerelated hygiene, nutrition, comprehensive parenting, and infant development. As soon as the "Canon of Medical Science" was written, it was immediately distributed in many copies. One hundred years after the death of Ibn Sina, the "Canon" became famous throughout Europe. In the 12th century, the Canon was first translated into Latin. In the XIII century - in the ancient Hebrew language, and later spread to many inscriptions. Canon was one of the first books to be published in the 15th century. This book served as an encyclopedia of medicine for many centuries and was the only necessary book on the table of doctors. Until the middle of the XVII century, classes in all European universities were conducted on the "Canon".

We should follow the path set by such scientists and help to take care of our health and the health of our relatives. You should explain to each other the importance of health for human life, the importance of maintaining it in human life, the dangers of microbes, the diseases of dirty hands, ways to avoid infections and coronaviruses.

In ancient times, according to the ancient custom, the bride did not call her husband's relatives by their first names. She was accustomed to give each of them a different name (depending on age or status in the family). For example, the bride used to give names for girls like kara koz, bikesh, shyraylym, yerkezhan and for boys or men aydarlim, shyrak, teteles, mirza aga, tore mirza aga and biy aga.

Other forms of taboo words are also directly related to the forces of nature, the names of deadly 
diseases, and predators. In other words, instead of calling smallpox directly, we used to call it as aulie, korasan, meiman and konak due to the belief that it "infects" and "sticks". Also, we used to call a wolf as itkus, kara kulak and ulyma due to the belief that If we call a wolf by its name as "wolf" it will attack our cattle. In the same way, if we find a synonym for this epidemic without naming it, maybe we can get rid of it quickly. We think that if we respect the traditions of our ancestors and contribute to the good, there will not be any disadvantages of it.

\section{REFERENCES}

1. Akhmetov A. Taboos words and euphemisms in the Turkic languages. Almaty: Gylym, 1995.

2. Ibn Sina. Canon of medical science. Moscow, 1994. Vol.1.

3. World Health Organization. Infection prevention and control during health care when COVID-19 is suspected. https://www.who.int/publicationsdetail/infection-prevention-and-control-duringhealth-care-when-novel-coronavirus-(ncov)infection-is-suspected-20200125

4. Remuzzi A., Remuzzi G. COVID-19 and Italy: what next. Lancet, 2020.

5. Giacomelli A., Pezzati L., Conti F. Self-reported olfactory and taste disorders in SARS-CoV-2 patients: a cross-sectional study. Clin Infect Dis. 2020. doi: 10.1093/cid/ciaa330

6. Richardson P, Griffin I, Tucker C. Baricitinib as potential treatment for 2019-nCoV acute respiratory disease. Lancet, 2020.

7. Guan W.J., Ni Z.Y., $\mathrm{Hu}$ Y. Clinical characteristics of coronavirus disease 2019 in China. N Engl J Med. 2020 doi:10.1056/NEJMoa2002032. 